\title{
Pragmaticalization (defined) as grammaticalization of discourse functions ${ }^{1}$
}

GABRIELE DIEWALD

Abstract

The article discusses definitions of grammaticalization, pragmaticalization and (inter)subjectification in order to clarify the relations between these terms. While grammaticalization is defined as a functionally motivated, complex type of language change, (inter)subjectification is shown to be a specific type of semantic change. Pragmaticalization, finally, is argued to represent a subclass of grammaticalization, which displays essential core features of grammaticalization processes, but is distinguished from other subtypes of grammaticalization processes by specific characteristic traits (concerning function and domain as well as syntactic integration). This is demonstrated by a survey of the diachronic development of several modal particles in German (among them aber, eben, ruhig). The more general theoretical stance taken here is that the notion of grammar and hence grammaticalization has to be conceived broad enough in order to encompass this type of discourse functions.

\section{Introduction}

This article takes up the question of pragmaticalization, subjectification and grammaticalization from a definitional point of view, asking whether (and if so, inhowfar) pragmaticalization and subjectification are distinct from grammaticalization. After briefly defining each of the three notions and relating them to each other, the suggestion is put forward that the notion of grammar and hence grammaticalization has to be conceived broadly enough in order to encompass the development of functional elements - like particular discourse functions - which transgress the traditional notion of grammar, but resemble traditional grammatical categories in their diachronic development and their synchronic behavior to such an extend that there is no positive argument to exclude them from grammar and grammaticalization. This will be illustrated by an overview of the rise of the grammatical category of modal particles in 
German, which nicely demonstrates the close connection between "grammatical" and "pragmatic" devices of language.

\section{Grammaticalization}

Grammaticalization is a complex multifactorial type of language change which does not consists of a single process but of a set of interacting processes. This was stated as early as in (1982) by Christian Lehmann, as is documented in the following quotation:

Grammaticalization is a process leading from lexemes to grammatical formatives. A number of semantic, syntactic and phonological processes interact in the grammaticalization of morphemes and of whole constructions. (Lehmann 1995 [1982]: V])

Summing up the discussion from the last decades of the 20th century, Traugott (2003: 644) states that "early grammaticalization can therefore be seen as a complex set of correlated changes", which she specifies as follows:

(i) structural decategorialization; (ii) shift from membership in a relatively open set to membership in a relatively closed one (i.e., from lexical category to syntactic operator category) in the context of a specific construction; (iii) bonding (erasure of morphological boundaries) within a construction; (iv) semantic and pragmatic shift from more to less referential meaning via invited inferencing [ . . . ], phonological attrition, which may result in the development of paradigmatic zero [ . . . ]. (Traugott 2003: 644)

Similar observations have been made by many others, for example by Haspelmath (1999), Heine (2003: 579), Himmelmann (2004: 31), Diewald and Wischer 2005. ${ }^{2}$ Consequently, the distinctive and unique feature of grammaticalization is generally seen in its particular combination and serialization of several processes and stages, which — among other things — find their repercussion in grammaticalization scales and paths, and in complex scenarios of successive contexts and constructions. Beyond these procedural factors, the essence of grammaticalization is defined here - by Lehmann and others - as follows:

Grammaticalization of a linguistic sign is a process in which it loses in autonomy by becoming subject to constraints of the linguistic system. (Lehmann 2004: 155)

Briefly summarizing a long discussion, grammaticalization is seen here as a complex, multilayered process leading "into grammar", whereby grammar is defined - again neglecting the intricacies of these notions - as paradigmatic, obligatory structures, which as a common core display some type of relational meaning. Thus, there is broad agreement that the following three features are essential ingredients for any definition of grammar: ${ }^{3}$ 
- obligatoriness

- paradigmaticity / paradigmatic integration

- relational meaning

The first two features, the obligatoriness and paradigmaticity or paradigmatic integration of grammatical signs, are closely linked to each other. Concerning the latter notion, it has been known since Jakobson that a grammatical category per definition consists of a paradigmatic opposition between at least two elements. One of them (typically the newly grammaticalizing one) constitutes the formally and notionally marked element which is cast in opposition to the formally and notionally unmarked zero element (which, in addition, is used as the neutralization stage of the opposition). Therefore, if any form or construction is grammaticalized then, by definition, it builds an oppositional pair with another item and, in virtue of this, is a member of a paradigm.

The paradigmatic integration of a sign refers to the fact that the members of a grammatical paradigm, which as a whole is constituted by a categorical value, are closely linked to each other, whereby we often find intracategorial subgroupings (cf. e.g., Lehmann 1995 [1982]).

Obligatoriness, on the other hand, refers to the fact that if there is a paradigm encompassing a set of oppositive values and if these values are to be addressed, then a choice has to be made between its members, and - no matter whether there is a zero marked element or not - there is no way of omitting this information. For an exemplification of this see Radtke (1998: 10), who with reference to the verbal categories of German states the following: "[ . . . ] der Sprecher [hat] keinerlei Freiheit bezüglich der Frage, ob eine Verbalkategorie gewählt werden soll oder nicht. Er muß sich hier für jeweils eine Verbalkategorie entscheiden, und zwar für genau eine" ['the speaker has no freedom at all with regard to the question whether to choose a verbal category or not. He has to choose one verbal category respectively, that is to say, he has to choose exactly one'].

As is well-known, the notions of obligatoriness and paradigmaticity are matters of degree, i.e., grammatical categories can form more or less clear-cut paradigms and the choice among their members can be more or less obligatory. Although it is not possible here to discuss this problem at any length some brief remarks are in place. ${ }^{4}$ According to Lehmann (1995 [1982]: 12) obligatoriness is a useful criterion although it is not "an absolute one", as "[s]omething is obligatory relative to the context; i.e., it may be obligatory in one context, optional in another and impossible in a third context". Among his examples are the different degrees of obligatoriness of the category of number in nouns in Latin versus Turkish. For the sake of clarity, the full quote is given here:

Take, for instance, the category of number. In Latin, every noun form compulsorily belongs either to the singular or to the plural; the speaker cannot choose to leave the 
number unspecified. Here the criterion correctly decides that number is a grammatical category of Latin. In Turkish, most nouns may be specified for number by adding a plural suffix. Some nouns may not, for instance terms of nationality or profession if they form the predicate. No noun may be specified for number if preceded by a cardinal numeral. In most other contexts, number is optional; i.e., the unmarked form may signify the singular or the plural. Is number obligatory in Turkish or not? Certainly not nearly as obligatory as in Latin. Should we therefore say that number is not a grammatical category of Turkish? Would it not be more illuminating to say that number is more grammaticalized in Latin than in Turkish? (Lehmann (1995 [1982]: 12)

German examples to illustrate the existence of different degrees of obligatoriness in grammatical paradigms are, on one end of the scale, paradigms whose membership choices are 100 percent obligatory and subject to grammatical rules, as in morphological paradigms like case marking in noun phrases. On the other end of the scale, there are paradigms like the voice distinctions between active and passive, which in German undoubtedly are paradigms counting among the members of the verbal grammatical category although the choice among them is not subject to language internal rules (see below).

Therefore, in order to make sensible use of the term obligatoriness, a distinction is drawn here between language internal obligatoriness, which is steered language internally and is thus subject to formal triggers (like concord, case selection, etc.), and communicative obligatoriness. This latter term is intended to capture the fact that many categories are obligatory in the sense that they have to be realized in the relevant position, i.e., the speaker cannot leave them unspecified if $\mathrm{s} /$ he does not want to produce incorrect utterances, but the choice among the paradigmatic members of the category is not determined by language internal features but by the communicative intentions of the speaker.

As already mentioned, an example of this second type of obligatoriness are the voice distinctions in German, i.e., the choice between the active and the two passive constructions, the werden-passive, and to the so-called dative passive. Both passives are realized as periphrastic constructions which can be grouped into a paradigm together with the active verb form as the unmarked member (e.g., active: Das Unternehmen überweist dem Verein die ganze Summe. 'The company transfers to the society the full amount'; werdenpassive: Die ganze Summe wird dem Verein vom Unternehmen überwiesen. 'The full amount is transferred to the society by the company'; dative passive: Der Verein bekommt vom Unternehmen die ganze Summe überwiesen. 'The society receives the full amount from the company'). The choice among one of the members of this paradigm is completely steered by the intentions of the user, i.e., by communicative obligatoriness. There is no instance where the use of one of the category members would be obligatory due to language internal reasons (see Diewald [2008] and [2010] for a more extensive treatment). 
Both types of obligatoriness may be described by conditional sentences, which in the protasis name the conditions or restrictions which induce the speaker to make a particular choice. In the case of language internal obligatoriness, these conditions are formal triggers, therefore the basic schema is: "If form $\mathrm{x}$, then form $\mathrm{y}$." In the case of communicative obligatoriness, the conditional protasis will contain reference to the speaker's intentions. Thus the formula can be given as follows: "If intention $\mathrm{x}$, then form $\mathrm{y}$. ."

For the use of the werden passive, which above has been described as a communicatively obligatory category, the conditional formula may be spelled out as follows (neglecting lexical restrictions on passives, etc.): "If the speaker wants to (i) put the theme into the privileged topological position at the beginning of the sentence, and (ii) keep the lexical verb of the corresponding active sentence, and (iii) avoid a marked linear order (which in this case would be a topicalized object), then the speaker must use the werden passive (given it is possible at all)."

Another important point should be noted: In opposition to word fields or semantic domains of referential items (which tend to constitute open classes), paradigms display a tightly integrated semantic structure with one categorial label, which might be called an "archiseme", and a given (usually small) number of semantic oppositions defining the distinct oppositive values (which, in turn, leads to closed class sets). Not amazingly and in parallel to the structural features of paradigms, the semantic feature, too, reflects varying degrees of grammaticalization. ${ }^{5}$

The third definitional criterion, the relational meaning structure or the inherent indexicality of grammatical items has first been mentioned by Jespersen (1992 [1924]) and Jakobson (1971 [1957]), who dubbed indexical grammatical signs "shifters". Since then many other linguists have subscribed to this notion. Thus, Anderson (1985: 172), Traugott and König (1991: 189), Diewald (1991), or Langacker $(1985,2002)$ - to name just a few — emphasize the relational structure of grammatical items. According to this line of thought, grammatical categories have a common core of meaning or function which consists in their relational structure, that is, a grammatical sign establishes a link between the linguistic element it modifies and some other entity (typically the deictic origo or one of its "derivatives"). Although it is not possible here to give a full account of the various kinds of indexicality in grammatical relations, nor of the particular distinctions between grammatical relational structures and lexical relational structures (for this confer Diewald 2010), it should be noted that grammatical relations may contain a deictic relation in the literal sense of the term as well as different types of derived relations (i.e., more abstract indexical relations).

A deictic relation in the literal sense is a relation between the actual speech situation, the deictic origo, and the linguistic utterance (or some part of it), i.e., a 
relation between the "speech event" and the "narrated event" in the sense of Jakobson (1971 [1957]: 133). In this case, the utterance is immediately linked to the communicative event. Straightforward examples for this are categories like tense or mood.

In derived indexical relations, which are frequent in grammatical categories, the relational structure is transferred from the genuinely deictic relation to the syntagmatic and paradigmatic planes of linguistic structure, thus producing different types of relational structure and layers of grammatical function. Although the derived relational structures are not deictic in the strict sense, they still contain the relevant relational structure of connecting the linguistic item which is modified by the grammatical sign in question to some other instance which in turn functions as the origo. In these relations, the speaker's perspective is encoded in an indirect way, but it is nevertheless retrievable by tracing back the derived relations to the current speech events. This unerasable anchoring in the speaker's current coordinate system is what already Bühler (1982 [1934]) recognized as the deictic foundation of grammatical meaning; and it was also Bühler who first postulated that more abstract grammatical relations are derived by transferring the relational structure of the deictic process from its original pointing field to other fields of pointing.

Anaphoric pronouns are an obvious example for derived relational structures. Rather than representing a deictic relation between the speaker origo and the uttered proposition, they represent a relation between elements of different, successively uttered propositions. They display a derived relational structure which does not directly refer back to the deictic origo but to some other zero point being used as the origin of the localization process. The same applies to conjunctions, the basic semantic content of which quite obviously contains a relational structure usually serving to link clauses. Thus, the conjunction but in utterances like, The weather is fine, but too hot for her, points back to the preceding clause and relates it to the following one. A paraphrase of this type of realization of the relational structure is: 'Go back to the (derived) origo, which is a proposition (proposition 1); from there interpret proposition 2 as being in a particular semantic relation to proposition 1 (according to the semantic features of the conjunction)'. It is this type of a derived syntagmatic relation that is relevant for the explanation of the grammatical function of modal particles, as will be discussed in Section 5.

Another important point should be noted here: Relational meaning per se is not restricted to grammar or to demonstrative adverbs like here or tomorrow. Instead, there are other lexical elements which encode relational meaning, too (e.g., adverbs like down, in the front, nouns like mother, daughter, verbs like come or bring). However, it is contended here that the relational meaning encoded in grammar is functionally different from relational meaning encoded in lexical material like the items cited in brackets, and that this in principle can be captured by the fundamental opposition between the two semiotic processes of Zeigen 
('pointing') and Nennen ('characterizing') that has been discovered by Bühler and that motivates his distinction between deictic signs and nondeictic signs (cf. Bühler 1982 [1934]: xxix, 86-88 and passim).

Summing up the discussion of relational meaning, we may note that it is possible to distill an abstract feature which is the common denominator of grammatical meaning: the existence of a basic relational structure, which may be applied to different pointing fields, thus achieving deictic, anaphoric and other connective relations.

The admittedly condensed and sketchy explanation of the three definitional criteria (obligatoriness, paradigmaticity and relational meaning) given so far has shown that all of them are gradable, i.e., matters of degree, bringing about clines between the poles of grammatical and lexical. Furthermore, it should be kept in mind that none of the three criteria is distinctive in itself. Instead, they have to be considered in combination in order to judge the degree of grammaticalization of an item.

From the foregoing discussion the following consequences arise for a definition of the notion of grammar:

- grammar is not restricted to morphosyntactic phenomena of a particular kind (e.g., inflectional morphology);

- grammar is not restricted to a particular kind of meaning beyond the relational component mentioned.

- grammar is not restricted to a particular functional plane (i.e., case marking, tense marking, sentential relations, subordination, etc.).

This of course means that the range of possible grammatical categories has to be extended beyond the traditional set, which has developed over time on the basis of evidence from the classical Indo-European languages. As a consequence of this, the position taken here is a broad view on grammar comparable to the one expressed in Traugott (2003: 626), who sees grammar "as structuring communicative as well as cognitive aspects of language", and therefore includes a much wider range of phenomena, e.g., "focusing, topicalization, deixis, and discourse coherence", into the realm of grammar.

\section{Subjectification}

Subjectification is treated here - in line with Traugott and others - as a particular type of semantic change. This definition can be derived directly from the famous description of the tendencies of semantic change in Traugott's seminal paper of (1989). The three tendencies, which in their central aspects have remained unchanged in all later modifications of the concept, are quoted here once more for convenience: 
Tendency I: Meanings based in the external described situation $>$ meanings based in the internal (evaluative/perceptual/cognitive) described situation. Tendency II: Meanings based in the external or internal described situation > meanings based in the textual and metalinguistic situation.

Tendency III: Meanings tend to become increasingly based in the speaker's subjective belief state/attitude toward the proposition. (Traugott 1989: 34-35)

As is very clear from the wording of this quote, the development described here - beyond and above change in the semantic domains - also involves some functional changes concerning the semiotic status of the item in question. It develops from mainly referential to mainly textual and connective functions, and further evolves to indexical grammatical functions. Obviously, this functional change is seen by Traugott and others as a merely concomitant factor, not as its central aspect. This becomes obvious in subsequent studies (e.g., Traugott 1999, Traugott and Dasher 2002), where the model is expanded, refined and generalized in order to account for as many instances of semantic change as possible. The modifications concern, first, the notion of subjectification, which is complemented by "intersubjectification" in order to account for social deixis (Traugott and Dasher 2002: 23-24), and second, the integration of possibly concomitant structural changes, especially the change of scope and topological features in the development of discourse markers (Traugott 1999). Notwithstanding these refinements, the essence of the model, i.e., the chronological ordering of the three stages as well as the description of the respective semantic and cognitive domains, has been retained.

The following quotes show that subjectification is seen as a semantic process, and that the reason for calling it subjective is - expressed as general as possible - a higher degree of speaker involvement, which is encoded in the linguistic item, the lexeme:

Subjectification is the semasiological process whereby SP/Ws [speakers/writers] come over time to develop meanings for Ls [lexemes] that encode or externalize their perspectives and attitudes as constrained by the communicative world of the speech event, rather than by the so-called "real-world" characteristics of the event or situation referred. (Traugott and Dasher 2002: 30)

[...] subjectification typically involves making SP/W attitude explicit. (Traugott and Dasher 2002: 97)

Finally, the authors draw a parallel to metaphorical semantic change by classifying subjectification as a type of metonymy:

And, most importantly, subjectification can be understood as a type of metonymyassociation with $\mathrm{SP} / \mathrm{W}$ in the strategic course of speaking/writing. (Traugott and Dasher 2002: 81) 
Thus, we may specify our definition of subjectification as follows: Subjectification is a type of semantic change belonging to the subclass of metonymic change.

As metaphorical as well as metonymic processes are known to play a prominent role in grammaticalization, the insight of subjectification being a subclass of metonymization consequently raises questions about the relationship between subjectification and grammaticalization, which has figured prominently in dispute on grammaticalization in the last years. While earlier studies tended to identify grammaticalization with subjectification, there is general agreement today, that grammaticalization and subjectification are not identical, and that both processes may occur in parallel but do not have to. ${ }^{6}$ Traugott herself makes this clear:

Subjectification in grammaticalization is the development of a grammatically identifiable expression of speaker belief or speaker attitude to what is said. Like the original hypothesis [...] subjectification is not limited to grammaticalization but can also be found in lexical change, for example, in such well-known cases of pejoration as boor 'countryman, farmer' > 'crude person'. (Traugott 2003: 633-634, emphasis mine)

Summing up this section we may state: While grammaticalization is a complex multilevel diachronic process leading towards grammar, subjectification is a particular type of semantic change, leading to meanings "based in the speaker's subjective belief state/attitude toward the proposition" (Traugott 1989: 35 ). Though subjectification is often found as one component of grammaticalization processes, it is independent of and not restricted to it.

Subjectification or subjective meaning, i.e., speaker-based meaning, has a very close natural connection to pragmatics, as the concept of "speaker" is the central feature of any pragmatic aspect of language. And this is the point, where the third term, pragmaticalization, needs to be introduced into the discussion.

\section{Pragmaticalization}

The term pragmaticalization is discussed here as it is used in studies on the rise of discourse markers and modal particles. It usually becomes relevant in certain instances of change, where the borderline between subjectification and grammaticalization is problematic, and the target, the endpoint of the change in question, does not fall into the range of grammatical categories in the traditional understanding of the term. That is, pragmaticalization - at least to the author's best knowledge - has not been defined in its own right up to now. Instead, it has been employed in order to preserve the domains of "grammar" and "pragmatic or discourse functions" as clearly distinct domains. Of the rich discussion on the topic, only a small selection can be referred to here (cf. Erman and Kotsinas 
1993, Traugott 1999, Tabor and Traugott 1998, Aijmer 1997, Vasko and Fretheim 1997, Barth and Couper-Kuhlen 2002, Lima 2002, Gohl and Günthner 1999, Günthner 1999, Autenrieth 2002, Wegener 1998, Wegener 2002, Auer and Günthner 2005).

As mentioned, most of theses studies discuss the problem of the definition and delineation of the functional domains of particles and discourse markers. They ask whether the development of those particles from other elements should be subsumed under the heading of grammaticalization, or whether it should be treated as a separate process, which is usually dubbed "pragmaticalization" or "subjectification". Thus, Aijmer (1997) — in her work on I think - suggests that a sharp line ought to be drawn between grammaticalization on the one hand and pragmaticalization on the other. In Aijmer's view, the former process (i.e., grammaticalization) "is concerned with the derivation of grammatical forms and constructions (mood, aspect, tense, etc.) from words and lexical structure", whereas "pragmaticalized items", i.e., items having undergone a process of pragmaticalization, involve a "speaker's attitude to the hearer" (Aijmer 1997: 2). It is, however, difficult to conceive how a separate "cline of pragmaticalization" (Aijmer 1997: 6) should be established in parallel to grammaticalization scales, since the descriptions which Aijmer gives of both supposedly distinct processes are not mutually exclusive, and thus may equally apply to one item.

Günthner (1999: 437) considers it plausible to treat the fact that the functional domain in the development of German obwohl from conjunction to discourse marker shifts from "purely grammatical functions" to "conversational functions" as an argument in favor of a distinct process of pragmaticalization, but goes on to point out that the development of discourse particles is indiscernible in many formal and semantic aspects from "proper" grammaticalization processes, defined in terms of Lehmann's grammaticalization parameters (Lehmann 1985); thus, the distinction between pragmaticalization and grammaticalization becomes minimal.

In a similar line of reasoning, Barth and Couper-Kuhlen (2002), who treat the development of discourse functions in final though in English, suggest that "pragmaticalization" ought to be subsumed as a specific subtype under the broad heading of grammaticalization, which deviates in some aspects from prototypical cases of grammaticalization but is too similar to be treated as "a separate, independently definable process" (Barth and Couper-Kuhlen 2002: 357, see also Lima 2002). The following quote from a paper by Günthner and Mutz (2004) nicely illustrates the dilemma:

This type of change which leads to discourse and pragmatic markers, to elements which organize, structure, and contextualize discourse with respect to discourse-pragmatic concerns and not with respect to sentence-grammatical concerns (e.g., congruence, binding), contradicts classical grammaticalization. (Günthner and Mutz 2004: 98) 
That is, while in her paper of (1999) Günthner still tries to reconcile the conflicting observations, in the later paper this effort is given up. And despite the fact that the diachronic development of discourse markers in all relevant structural and semantic aspects is a paradigm example of grammaticalization, the authors diagnose a "contradiction" to grammaticalization. Without further qualifying how we should safely distinguish between "sentence-grammatical concerns" and "discourse-pragmatic concerns", they seem to take this distinction to be the cutting edge criterion. Probably, this decision originates in the fact that the function or meaning expressed by these elements does not fit into the traditional range of meanings and functions which are allotted to grammatical categories.

Auer and Günthner (2005), on the other hand, suggest giving up the distinction between grammaticalization and pragmaticalization, and - in line with this article - argue for a broader notion of grammar. They explicitly include means for structuring discourse in the domain of grammar and also point to the fact that grammaticality is a gradual phenomenon. ${ }^{7}$

An approach with a slightly different perspective is taken in a study on the development of Italian tuttavia 'however' from a temporal adverbial to a textual connective by Giacalone Ramat and Mauri (2010). They argue that this development is an instance of grammaticalization for functional and semantic reasons, although - as they demonstrate - those of Lehmann's parameters which refer to morphosyntactic processes are not distinctive in this case. In order to be able to subsume phenomena like the development of textual connectives and other "pragmatic" markers under the heading of grammaticalization, in a follow-up paper the authors suggest to distinguish between standard and nonstandard grammaticalization which they define as respectively displaying or not displaying the reflexes of the grammaticalization parameters (Giacalone Ramat and Mauri 2009).

As the development of discourse markers and particles often leads to a discussion of the degree of applicability of Lehmann's grammaticalization parameters to different types of grammaticalization processes (see Traugott 2003, Günthner and Mutz 2004, Giacalone Ramat and Mauri 2009), some remarks on this issue are in place here. First, as the parameters aim at full coverage of all phenomena possibly observable in grammaticalization processes in languages of various typological make-up, it is not necessary for all six parameters to render relevant results for one particular item investigated in order to speak of grammaticalization. Therefore, this paper resorts to the three concepts of obligatoriness, paradigmaticity and relational meaning, which can be tied back to (a combination of) the parameters.

Second, the older the grammaticalization process, the more it is likely to leave traces on the syntactic and morphological levels of linguistic structure. Younger instances of grammaticalization, like the case of the modal particles 
in German, usually do not (yet) show many reductive processes on these structural levels.

Third, the question of scope reduction (condensation) and its indicative force for grammaticalization as it was first raised by Lehmann caused some confusion due to the fact that the term scope is usually applied to semantic issues while Lehmann's postulate of scope reduction refers to structural features. This is obvious from the definition of scope given by Lehmann in his seminal paper of (1985). Scope, i.e., the parameter referring to syntagmatic weight, is defined there as "the extend of the construction which it [the item under grammaticalization, GD] enters or helps to form" (1985: 306). The associated process, i.e., condensation, is defined as follows: "The more the sign is grammaticalized, the less complex become the constituents with which it can combine. It also looses [sic] its predicativity, its ability to predicate" (1985: 308). While in instances of weak grammaticalization an item "relates to constituent[s] of arbitrary complexity", after condensation, i.e., after scope reduction, an item "modifies a word or stem" (1985: 309). As an example to illustrate scope reduction in this sense, Lehmann adduces the Latin preposition de as compared to the French preposition de: "Latin de takes a cased NP as complement, French de takes a caseless complement." (1985: 308).

In order to avoid further confusion and a mix-up of this notion of scope with "semantic scope", in later publications the name of this parameter was changed from "scope" to "structural scope" (e.g., Lehmann 1995 [1982]: 143).

Thus, in contrast to what is sometimes assumed (Traugott 2003: 643, Günthner and Mutz 2004: 98) there is no contradiction in the observation that in the same grammaticalization process, structural scope is reduced (Lehmann's postulate), while semantic scope is expanded. This latter change is exactly what occurs in the case of the modal particles in German, while - due to the young age of this grammaticalization process and its specific source constructions - structural scope condensation is not (yet?) prominently discernible. Thus, Traugott's observation of scope extension in the grammaticalization of discourse markers (Traugott 2003), which is supported by the findings of other researchers, is no counterevidence for the postulate that structural scope in the sense of Lehmann's use of the term is reduced in grammaticalization.

Summarizing the results of this discussion it may be stated that the diachronic processes - be they called grammaticalization or pragmaticalization - that are observed in the large class of items called discourse particles and discourse markers are virtually indistinguishable from "normal" grammaticalization processes as far as structural, semantic and chronological features are concerned. The only difference lies in the perceived results of the diachronic development.

And while so far no sufficiently explicit definition of grammar has been available, ${ }^{8}$ it is well-known that neither discourse particles nor modal particles 
traditionally have been treated as belonging into the realm of grammar. It seems that pragmatic meaning generally has not been regarded as the right meaning for true grammar. The dividing line in this debate - which has been going on for quite a time now - seems to run between "true" grammatical function and "merely" pragmatic function, which illustrates the tendency of linguistics in general and grammaticalization studies in particular to regard the traditional set of familiar grammatical categories as the semantic-functional benchmark for evaluating grammatical categories.

In the rest of this article the diachronic development of modal particles, which definitely do have a discourse pragmatic function, is argued to constitute an exemplary case of grammaticalization, and the function they realize is claimed to be a truly grammatical function.

\section{Grammaticalization and pragmaticalization as observed in the development of modal particles in German}

Since the seminal work by Weydt $(1969,1977,1979,1989)$ modal particles have been the subject of a great number of studies undertaken from different perspectives and different theoretical backgrounds. It is not the purpose of the following pages to render this research history or the present state of the art. Nor is it intended to give a complete account of the diachronic development of single particles or the complexities of their usages in present-day German. Instead, the modal particles of German are chosen here in order to support and illustrate the claims made in the preceding sections on grammatical categories, grammaticalization and pragmaticalization. Therefore, the examples used are kept simple and schematic. It should be noted, though, that the present-day German examples quoted in the following can be verified as authentic usage of the spoken language or of the informal language found in those communication formats of the internet which are very close to the spoken word. ${ }^{9}$

Claiming that German modal particles represent a grammatical category in PDG,${ }^{10}$ it is useful to quickly run again through the criteria mentioned in Section 2 as pivotal for defining a grammatical sign. These are the following three:

- obligatoriness

- paradigmaticity / paradigmatic integration

- relational meaning.

All three features can be found in the class of modal particles today. This will be illustrated immediately by the prototypical constructions encoding questions in German. There are two standard ways of expressing an unmarked interrogative speech act. One is by using the modal particle denn, like in (1): 


\section{(1) Kommst du denn mit?}

Are you DENN coming along?

The other option is to use the same construction type without particle as in (2):

(2) Kommst du mit?

Are you coming along?

The functional difference between the two is the following: By using the modal particle denn, the question is marked as being a consequence of the communicative interaction that precedes it. Thus, denn indicates a consecutive relation between a pragmatically given unit and the relevant situation. It marks the speech act as a noninitial, reactive turn. Particle-less questions, on the other hand, mark the question as the initial turn of an adjacency pair consisting of an initiating interrogative turn and a reactive turn (preferred case: an answer).

This function, i.e., marking a turn as noninitial by relating it to a presupposed, pragmatically given unit, is not restricted to denn, but is the common denominator of all modal particles of German, independent of the speech act type they are associated with. And it is this function which qualifies the modal particles in German as a grammatical category on functional-semantic grounds (Diewald 2006, 2007). This relational structure — in a somewhat simplifying manner — can be given as follows:

pragmatically given unit $\leftarrow$ (modal particle $\&$ utterance in the scope of the modal particle)

Stating that the common semantic denominator of modal particles is their capacity to mark the utterance as a reactive turn does not mean that the occurrence of modal particles is restricted to noninitial turns. On the contrary, the particle meaning allows the speaker to manipulate the communicative context by implying (pretending) the existence of a foregoing initial turn. Uses of modal particles in turns opening up a communicative encounter support the position held in this paper. For example, opening up questions with denn (like Was kann ich denn für Sie tun?, Was hätten Sie denn gern?, Was darf es denn sein?, roughly: 'What can I do for you?') are stereotypical openings of customer talk and sales conversation. While it is obvious to both interlocutors that in effect there is no preceding turn, by using the denn-question the speaker insinuates that there has been some communicative exchange to which $\mathrm{s} /$ he reacts and that $\mathrm{s} /$ he is not impolitely imposing on the other person. ${ }^{11}$ Thus, the fact that modal particles do occur in initial turns is not a counterargument against their common meaning postulated here.

A further point must be briefly touched here. Beyond the common feature of marking the turn as noninitial, each modal particle carries a lexeme specific abstract meaning, which is derived from its lexical source and which accounts for the distinctive value of each particle in the new grammatical paradigm. In 
the case of the interrogative particles, denn - in consequence of its diachrony - has a consecutive meaning, while other interrogative particles like vielleicht or etwa display other particle specific meaning components.

As to the question why this relational structure should be regarded as grammatical meaning, the following points should be considered:

- In referring "back" to something that is treated as communicatively given, albeit unexpressed, the modal particle marks the utterance which contains it as noninitial.

- As the interchange of initial and responsive turns is the constitutive feature of spoken interaction, this relational function of the modal particles clearly is an indispensable grammatical device for structuring discourse.

In short: With the help of modal particles, the speaker marks the turn as noninitial and responsive, and thus is able to manipulate and modify the ongoing interchange. This is a pragmatic meaning, as it structures discourse, but it is no less a grammatical meaning than the meaning of conjunctions or of tense markers is grammatical. It has the same relational structure and the same type of indexical core function.

As to the features of obligatoriness and paradigmaticity, the modal particle denn in questions displays these features in the way that is postulated here for grammatical categories. First, it is particularly important to note that the distribution of the two interrogative constructions (1) versus (2) is complementary, which is to say, the two constructions form a paradigmatic opposition. There are contexts where it would not be possible to leave out denn in a question, i.e., denn is communicatively obligatory in these contexts. ${ }^{12}$ On the other hand, there are contexts, which call for particle-less questions. Thus, we have a paradigmatic opposition, which, however, does not belong to the group of traditionally acknowledged grammatical categories.

Furthermore, beyond the small paradigm of interrogative constructions, the whole class of modal particles of German shows a high degree of paradigmatic organization. Modal particles are defined as a word class that is constituted by the clustering of specific formal, structural, and functional features. ${ }^{13}$ Typically, as can be looked up in standard reference grammars as well as in the linguistic literature, they are the following:

- noninflecting linguistic elements

- syntactically integrated

- restricted to the middle field of the sentence

- not allowed in sentence-initial position in V2-clauses and therefore treated as elements without constituent value

- relational meaning (relating propositions and speech act alternatives, one of which is not textually expressed but treated as "given"). 
While these features account for the external separation from other word classes, the internal paradigmatic organization of the class of modal particles is comparable to the internal organization of other grammatical paradigms. Beyond the interrogative particle denn shown above, this can be seen by the opposition of modal particles in statements, i.e., representative speech acts. Examples (3) to (5) are minimal pairs, only distinguished by the particle meanings.

(3) Das ist aber keine gute Idee.

'That is ABER not a good idea.'

[adversative with respect to the proposition: 'That is a good idea someone may think this; it is not true']

(4) Das ist ja keine gute Idee.

'That is JA not a good idea.'

[affirmative with respect to the proposition: 'That is not a good idea

— you and I already knew this ']

(5) Das ist eben keine gute Idee.

'That is EBEN not a good idea.'

[iterative with respect to the proposition: 'That is not a good idea - I

held this opinion before and I hold it and say it now']

While the specific semantic content of aber is adversative, that of $j a$ is affirmative, and that of eben iterative, i.e., it states a repetition of the pragmatically given proposition in the present scene. ${ }^{14}$

As modal particles are sensitive to speech acts and sentences types, "minimal pairs" such as the ones given above in most cases apply only to subgroups of the whole class. As the organization into subparadigms is a common feature of grammatical paradigms this fact does not constitute a counterargument against treating modal particles as a grammatical paradigm. To conclude this part it may be noted that

- modal particles have a relational meaning (relating the utterance to a pragmatically given unit),

- modal particles form a word class paradigm and various subparadigms,

- modal particles are communicatively obligatory.

In short: they show all attributes of a grammatical category in present-day German. The following paragraphs give a very brief and superficial look at their diachronic development, which will be shown to be a prototypical case of grammaticalization. However, it should be noted that the following sketch in no way claims to provide a complete or comprehensive picture of the diachronic development of each particle nor their wealth of meaning variants at any synchronic stage (for a detailed description of semantic ramifications, see 
for example König et al. 1990). The purpose of the following synopsis is to remind the reader of the fact that the paths of development of modal particles are in congruence with results and data from many grammaticalization studies on a large variety of categories.

The ultimate source lexemes and source constructions of modal particles display a considerable span of variation - ranging from "original" particles with other than modal function (e.g., ja), adverbs (schon, OHG scono, adverb of adjective sconi), adjectives (eben, gleich, ruhig), to two-word syntagms ( $n i$ ware $>$ nur, vil lihte $>$ vielleicht), etc.

Table 1 presents a sketch of a possible grammaticalization channel of modal particles. The three particles denn, aber and eben serve as examples for the variety of source lexemes. ${ }^{15}$

Table 1 shows the diversity of possible sources which converge in the grammatical paradigm of modal particles. It also shows that - notwithstanding their diverging origins - the modal particles undergo parallel diachronic stages of development. We can distinguish three stages:

- Stage (i) represents the source: here we have original particles or members of other word classes with demonstrative or relational meaning.

- Stage (ii) marks a relation between two textually expressed events/ instances.

- Stage (iii) shows the fully developed grammatical markers indicating the noninitial state of an utterance.

Table 2 adds further evidence as it shows the development of particles deriving from adjective sources, which is a highly frequented path of grammaticalization for modal particles in German.

As has been shown and empirically tested in earlier studies (e.g., Hentschel 1986, Autenrieth 2002, Diewald 1999, Diewald and Ferraresi 2008), the development of these particles displays all the factors typical for grammaticalization. All modal particles investigated so far in their diachronic development show the interplay of general grammaticalization paths concerning the semantic development, the functional development, and the inherent semantic core structure of the items in question. The core structure remains stable in its essence, but is reinterpreted for its broad semantic or functional domain, which becomes more and more abstract, less referential, and more grammatical. This semantic change, or more precisely: this shift of the relational core structure to various domains, is accompanied by a functional change corresponding to the general tendencies set up by Traugott, which transcends word-class boundaries (Diewald 2006). The result is the coexistence of several heterosemes whose functional spectra, though seemingly unrelated from a purely synchronic perspective, retain the successive gradient steps of regular grammaticalization. 
Table 1. Successive stages in the grammaticalization of the German modal particles (adapted from Diewald et al. 2009)

\begin{tabular}{|c|c|c|c|}
\hline \multirow[t]{2}{*}{$\begin{array}{l}\text { 1st stage } \\
\text { referential function: } \\
\text { major word class, } \\
\text { constitutent }\end{array}$} & $\begin{array}{l}\text { old demonstrative } \\
\text { particles/adverbs }\end{array}$ & $\begin{array}{l}\text { adverbs with } \\
\text { relational } \\
\text { semantics }\end{array}$ & $\begin{array}{l}\text { adjectives with } \\
\text { relational } \\
\text { semantics }\end{array}$ \\
\hline & $\begin{array}{l}\text { denn } \\
\text { origin in local } \\
\text { demonstrative }\end{array}$ & $\begin{array}{l}\text { aber } \\
\text { origin in } \\
\text { comparative of } \\
\text { local adverb }\end{array}$ & $\begin{array}{l}\text { eben } \\
\text { origin in relational } \\
\text { spatial, concrete } \\
\text { adjective }^{16}\end{array}$ \\
\hline $\begin{array}{l}\text { 2nd stage } \\
\text { text-integrative/ } \\
\text { connective function } \\
\text { (inner-textual } \\
\text { grammatical function): } \\
\text { function word, } \\
\text { nonconstituent }\end{array}$ & \multicolumn{2}{|c|}{$\begin{array}{l}\text { successive/consecutive relation between } \\
\text { two textually expressed events/instances }\end{array}$} & $\begin{array}{l}\text { simultaneous/ } \\
\text { comparative } \\
\text { relation between } \\
\text { two events/ } \\
\text { instances }\end{array}$ \\
\hline & $\begin{array}{l}\text { denn } \\
\& \text { interrogative } \\
\text { speech act }\end{array}$ & $\begin{array}{l}\text { aber } \\
\& \text { proposition }\end{array}$ & $\begin{array}{l}\text { eben } \\
\& \text { so \& two } \\
\text { comparanda }\end{array}$ \\
\hline \multirow[t]{2}{*}{$\begin{array}{l}\text { 3rd stage } \\
\text { indexical-grammatical } \\
\text { function (deictic } \\
\text { grammatical function): } \\
\text { function word, } \\
\text { non-constituent, } \\
\text { restricted to middle } \\
\text { field }\end{array}$} & \multicolumn{3}{|c|}{$\begin{array}{l}\text { indicating noninitial state of utterance, i.e., discourse } \\
\text { grammatical value \& particle specific meaning }\end{array}$} \\
\hline & $\begin{array}{l}\text { denn as MP in } \\
\text { interrogative } \\
\text { speech acts: } \\
\text { consecutive } \\
\text { meaning }\end{array}$ & $\begin{array}{l}\text { aber as MP in } \\
\text { exclamative speech } \\
\text { acts: adversative } \\
\text { meaning }\end{array}$ & $\begin{array}{l}\text { eben as MP in } \\
\text { statements: } \\
\text { iterative meaning }\end{array}$ \\
\hline
\end{tabular}

As has been shown above, the categorical meaning of the class of modal particles can be characterized as marking the utterance as noninitial by relating it to a pragmatically presupposed proposition. If we would choose to call this a pragmatic meaning, then, we should also call the meaning of a tense category a pragmatic meaning because it is deictic and links the linguistic level to the communicative level in exactly the same way as does the class of modal particles. The only difference between them is their respective formal realization and their specific semantic/functional domain. 
Table 2. Successive stages in the grammaticalization of modal particles deriving from adjectives

\begin{tabular}{|c|c|}
\hline $\begin{array}{l}\text { 1st stage } \\
\text { referential function: } \\
\text { major word class constituent; } \\
\text { used as attribute or predicative } \\
\text { adjective, adverb }\end{array}$ & $\begin{array}{l}\text { various source meanings } \\
\text { - local relation, e.g., eben ('even, plain, smooth') } \\
\text { - concrete physical comparison, e.g., gleich ('equal') } \\
\text { - antonymic, evaluative relation, e.g., schon/schön } \\
\text { ('beautiful') } \\
\text { - privative relation, e.g., ruhig ('free of work'17, 'calm') } \\
\text { bloß ('naked, without cloths/weapons') } \\
\text { - possessive relation, e.g., eigentlich ('intrinsic, } \\
\text { original') } \\
\text { - } \text { numeric relation, e.g., erst ('first'), einfach ('onefold') }\end{array}$ \\
\hline $\begin{array}{l}\text { 2nd stage } \\
\text { text-integrative/connective } \\
\text { function (inner-textual } \\
\text { grammatical function): } \\
\text { function word, nonconstituent: } \\
\text { conjunction, scalar particle } \\
\text { constituent: adverb }\end{array}$ & $\begin{array}{l}\text { abstracted, homogenized meanings } \\
\text { - temporal meaning, e.g., eben ('right now') gleich } \\
\text { ('at once'), erst ('in the first place'), schon } \\
\text { ('already') } \\
\text { - privative or restrictive meaning ruhig ('motionless') } \\
\text { bloß ('only'), einfach ('simple'), eigentlich ('only') }\end{array}$ \\
\hline $\begin{array}{l}\text { 3rd stage } \\
\text { indexical-grammatical function } \\
\text { (deictic grammatical function): } \\
\text { function word, nonconstituent, } \\
\text { MP, } \\
\text { restricted to the middle field }\end{array}$ & $\begin{array}{l}\text { pragmatic meaning } \\
\text { indicating a noninitial state of an utterance, i.e., } \\
\text { discourse grammatical value and particle specific } \\
\text { meaning, substitutable by other modal particles: } \\
\text { - Da darf es ruhig ein bißchen später, so zwischen } 4 \\
\text { und } 5 \text { Uhr, sein. (Keil 1990: 45) } \\
\text { Da darf es schon/auch ein bißchen später, . . . } \\
\text { - Sie ist schon ganz nett. } \\
\text { Sie ist ja/doch ganz nett. } \\
\text { - Wie heißt gleich dein Hund? (Helbig 1988: 156) } \\
\text { Wie heißt denn/doch/eigentlich dein Hund? } \\
\text { - Wären wir erst wieder zuhause! (Helbig 1988: 137) } \\
\text { Wären wir nur/bloß wieder zuhause! } \\
\text { - Ich war einfach zu faul, das Licht anzudrehen. } \\
\text { (Thomas Mann, Zauberberg, 274, Paul/Henne 1992) } \\
\text { Ich war halt/eben zu faul, das Licht anzudrehen. } \\
\text { - Gibt's da eigentlich auch eine Messeermäßigung? } \\
\text { (Keil 1990, Bd. 2, S. 7) } \\
\text { Gibt's da denn auch eine Messeermäßigung? }\end{array}$ \\
\hline
\end{tabular}

If we chose to do that, and if we chose to call the development of these categories pragmaticalization, then we would have to call the development of all deictic grammatical categories pragmaticalization, because there is no definitional difference between them and the development of discourse markers. As a result of this decision, the extended notion of pragmaticalization would render the term grammaticalization superfluous or at least reduce its extension dramatically. 
As I hope to have made clear on the foregoing pages, I do not favor this option. Instead, I suggest opening up the notion of grammar to the systematic encoding of discourse relations and calling a development like the one witnessed in the German modal particles the grammaticalization of discourse functions.

I suggest that pragmaticalization is a specific instance of grammaticalization which shows the crucial features of grammaticalization processes and is only distinguished from other grammaticalization processes by the functional domain it leads to and by some concomitant structural features (e.g., low degree of syntactic integration). As pragmaticalization (understood in these terms) is one instance of grammaticalization among many others, there is no reason to treat it on par with grammaticalization, i.e., on the same hierarchical level, in a classification of types of language change.

\section{Conclusion}

In the first part, definitions of the three relevant terms have been offered. Grammaticalization is defined as a complex, multilayered process leading "into grammar", i.e., into paradigmatic, obligatory structures, which as a common core display some type of relational meaning. Subjectification is seen as a particular type of semantic change. The need to introduce the term pragmaticalization has been shown to be the outcome of an attempt to preserve the domains of "grammar" and "pragmatics" as clearly distinct domains. It has been argued that a more comprehensive notion of "grammar", which encompasses "pragmatic" functions, makes the latter term dispensable, or — if one prefers to keep it — restricts it to naming a specification of the superordinate process of grammaticalization. Given this terminological adaption, diachronic developments like the rise of the grammatical category of modal particles in German do no longer pose a problem to linguistic description, but can be easily treated as what they are: standard cases of grammaticalization.

Finally, the characteristics of the modal particles which are relevant in this context may be summarized as follows:

- Modal particles form a paradigm with several subdivisions and are obligatory (communicative obligatoriness).

- Modal particles have a discourse grammatical function (a particular type of relational meaning).

- Their development is an instance of grammaticalization, accompanied by that type of semantic change, which may be called subjectification. 


\section{Appendix A. Corpora}

KALI-Corpus: www.kali.uni-hannover.de, accessed on 21 July 2007

Bonner Frühneuhochdeutsch Korpus:

www.ikp.uni-bonn.de/dt/forsch/fnhd/, accessed on 5 November 2006

Bibliotheca Augustana: www.fh-augsburg.de/ harsch/augustana.html, accessed 3 March 2007

IDS-corpora: www.ids-mannheim.de, accessed on 7 June 2006

\section{Appendix B. Dictionaries}

$[D W B]=$ Deutsches Wörterbuch . Jakob und Wilhelm Grimm. Neubearbeitung. Akademie der Wissenschaften der DDR, Akademie der Wissenschaften zu Göttingen (eds.). Leipzig: Hirzel. 1965-.

Paul/Henne 1992 = Paul, Hermann. 1992. Deutsches Wörterbuch. 9., vollständig neu bearbeitete Auflage von Helmut Henne und Georg Objartel unter Mitarbeit von Heidrun Kämper-Jensen. Tübingen: Niemeyer.

\section{Notes}

1. Thanks are due to the Belgian Science Policy (Interuniversity Attraction Poles programme project GRAMIS 6/44) for partial funding of work on this topic. Correspondence address: Deutsches Seminar, Germanistische und Angewandte Linguistik, Leibniz Universität Hannover, Königsworther Platz 1, D-30167 Hannover, Germany. E-mail: gabriele.diewald@ germanistik.uni-hannover.de.

2. Cf. also Lehmann (1985), where six parameters of grammaticalization are correlated in order to form a complex instrument for measuring degrees of grammaticalization. Bybee (1985), in an empirical-typological study on the degrees of grammaticalization in markers for verbal categories, also uses a bundle of interdependent factors (addressing semantic, structural, morphological features as well as frequency). Heine (2003: 579) lists the following four mechanisms: "(i) desemanticization (or "bleaching”, semantic reduction): loss in meaning content; (ii) extension (or context generalization): use in new contexts; (iii) decategorialization: loss in morphosyntactic properties characteristic of the source forms, including the loss of independent word status (cliticization, affixation); (iv) erosion (or "phonetic reduction"), that is, loss in phonetic substance." Some pages later, Heine (2003: 583) makes it clear that these four mechanisms "and the way they are interrelated" account for the process of grammaticalization, "irrespective of how one wishes to define a 'distinct process'."

3. For a detailed discussion on this issue see Diewald (2008), (2010); cf. also Lehmann (1985), Bybee (1985: 27), Bybee, Perkins, and Pagliuca (1994: 2), Haspelmath (1998: 318), Dahl (2001), Plungian (1998), Mel’čuk (1976: 84), Radtke (1998: 10).

4. See also Wiemer and Bisang (2004), Himmelmann (2004, 1992), Lehmann (1995 [1982]), Plungian (1998), Diewald (2008, 2010), Diewald and Smirnova (submitted).

5. Again, confer Lehmann: "On the semantic side, the members of a paradigm have a common semantic basis with varying differentiae specificae. This would be brought out by a componential analysis and is reflected in traditional terminology by the fact that there is a generic 
category name for the whole paradigm and opposite names for the specific subcategories [...]. Such paradigmacity is gradually reached in the process of grammaticalization. Categories grammaticalized very little do not constitute such tightly integrated paradigms." (Lehmann 1995 [1982]: 135).

6. It should be noted here that this and the following only applies to the notion of "subjectification" as it is defined by Traugott. If the definition of subjectification proposed by Langacker $(1985,2002)$ is taken into account the picture changes radically as Langacker's concept of subjectification is much closer to the semiotic process of deixis and therefore closer to the notion of grammar proposed here.

7. The central hypothesis of Auer and Günthner (2005) is similar to the one suggested here. There are, however, notable differences in the definition of what constitutes a paradigm, and in the question of what type of meaning is expressed in grammatical items. The authors seem to restrict the notion of paradigm to its traditional meaning, i.e., "inflectional paradigm", while in the present paper the term is used to include paradigmatic relations of closed class sets independent of their morphological make-up. As far as the meaning of grammatical signs is concerned, Auer and Günthner describe grammatical items as semantically empty ((tendenziell) semantisch leer) and assume that it is this feature (which they also call offene Form 'open form'), which accounts for their grammatical function (2005: 354-355). In the present paper, on the other hand, the indexicality of grammatical signs is put down to an inherent relational meaning of the respective signs, which — though abstract to a high degree - carries some category specific semantic value and thereby serves to anchor the utterance in its communicative and textual context.

8. Cf. also Himmelmann (1992: 2): "Work in grammaticalization also hardly ever makes explicit the concept of grammar underlying a given investigation." Though it dates from the year 1992 this statement is still valid today.

9. The following findings of internet search runs render some authentic counterparts for sentences used here. Authentic counterpart of Example (3): The speaker answering to a foregoing suggestion produces the following utterance with the modal particle aber: Hallo! Das ist aber keine gute Idee *lach* Es gibt nämlich Kinder, die werden mit Zähnen geboren (http:// www.wer-weiss-was.de/theme76/article5218616.html, 2 February 2010).

Authentic counterpart of Example (4): The speaker talks about the Abwrackprämie and uses the modal particle $j a$ twice with the purpose of ironically referring to possible solutions known by everyone, but not observed. It is the second sentence containing $j a$ that directly corresponds to Example (4): Langhaltige Konjunkturhilfen müssen her. Aber dann müssten wir ja an die Billionen der Reichen ran . . Neeee das ist ja keine gute Idee. (entry 19.01.2009, 13:20:38), (http://www.busfreaks.de/strohrum/showthread.php?id=28923, 2 February 2010). Authentic counterpart of Example (5): the speaker, discussing a question about how to solve a technical problem, utters the following instance of the modal particle eben: [ . . ], aber das ist eben keine gute Idee, wie man sieht. [ . . ] (entry 15 Januar 2009 00:09) (http://forum. ubuntuusers.de/topic/c-struktur-problem-und-brett-vorm-kopf/ 2 February 2010).

10. The grammatical function of modal particles was discovered by linguists before, among them Krivonossov (1977) and Abraham (1991).

11. In this case there is reference to common ground in the form of shared knowledge about the specific situation (e.g., 'you are here to enter into a sales conversation with me') and communicative frames, containing e.g., the knowledge that sales people should approach customers, etc.

12. It should be noted here that — as described in Section 1 - obligatoriness and paradigmaticity are matters of degree. In interdependence with a range of limiting contextual factors, it is possible for speakers to choose among several functionally equivalent (or partly equivalent) ways of expressing a particular concept or communicative intention (e.g., by particular pro- 
sodic features or the choice of a completely different construction). In Section 1 this interdependence has been made explicit by the introduction of different kinds of conditional formula for the two types of obligatoriness. For the choice of a denn-questions the appropriate formula might be the following: If the speaker wants to (i) pose a question in its syntactically and prosodically unmarked form, and (ii) mark the turn as reactive, i.e., noninitial, and (iii) encode a consecutive meaning, then the speaker must insert the modal particle denn in the basic interrogative sentence.

13. The core of this class consists of the following 15 extremely frequent items: aber, auch, blo $\beta$, denn, doch, eben, eigentlich, etwa, halt, ja, mal, nur, schon, vielleicht, wohl (Helbig and Buscha 2001: 421).

14. The labels (adversative, iterative, etc.) indicating intraparadigmatic semantic oppositions are intended to be maximally abstract and comparable to similar distinctions known from other paradigms and classes of function words, e.g., from prepositions and conjunctions. The labels are not meant to account for the meanings of the heterosemes of the particles in other word classes. For example, to distinguish the adverb or adjective eben from wieder, the label iterative would not be sufficient, and a more extended semantic description would be called for. Nevertheless, it is claimed here that the abstract meaning labels for the paradigmatic oppositive values within the closed class of modal particles are abstracted from and compatible with the meanings of the lexical source items.

15. For details of their development, see Hentschel (1986), Diewald (1999), Autenrieth (2002), Diewald and Ferraresi (2008).

16. The semantic description of eben as incorporating a "spatial relation" includes "local relations", i.e., relations between no less than two points in the typical physical surroundings of humans as well as microscale relations between no less than two points which account for the evaluation of surface properties.

17. The meaning 'free of work' is the oldest attested meaning of the item, cf. DWB sub voce ruhig.

\section{References}

Abraham, Werner. 1991. The grammaticization of the German modal particles. In (Typological Studies in Language 19:2), 331-380. Amsterdam \& Philadelphia: John Benjamins.

Aijmer, Karin. 1997. I think - an English modal particle. In Toril Swan \& Olaf Jansen Westvik (eds.), Modality in Germanic languages. Historical and comparative perspectives (Trends in Linguistics: Studies and Monographs 99), 1-47. Berlin \& New York: Mouton de Gruyter.

Anderson, Stephen R. 1985. Inflectional morphology. In Timothy Shopen (ed.), Language typology and syntactic description, vol. III: Grammatical categories and the lexicon, 150-201. Cambridge: Cambridge University Press.

Auer, Peter \& Susanne Günthner. 2005. Die Entstehung von Diskursmarkern im Deutschen — ein Fall von Grammatikalisierung? In Torsten Leuschner \& Tanja Mortelmans (eds.), Grammatikalisierung im Deutschen (Linguistik — Impulse \& Tendenzen 9), 335-362. Berlin \& New York: Mouton de Gruyter.

Autenrieth, Tanja. 2002. Heterosemie und Grammatikalisierung bei Modalpartikeln. Eine synchrone und diachrone Studie anhand von eben, halt, e(cher)t, einfach, schlicht und glatt. Tübingen: Niemeyer.

Barth, Dagmar \& Elizabeth Couper-Kuhlen. 2002. On the development of final though: A case of grammaticalization? In Ilse Wischer \& Gabriele Diewald (eds.), New reflections on grammaticalization (Typological Studies in Language 49), 345-361. Amsterdam \& Philadelphia: John Benjamins. 
Bühler, Karl. 1982 [1934]. Sprachtheorie: Die Darstellungsfunktion der Sprache. Stuttgart: UTB. [English edition: Karl Bühler. 1990. Theory of language: The representational function of language (Foundations of Semiotics 25). Amsterdam \& Philadelphia: John Benjamins.]

Bybee, Joan L. 1985. Morphology: A study of the relation between meaning and form (Typological Studies in Language 9). Amsterdam \& Philadelphia: John Benjamins.

Bybee, Joan L., Revere D. Perkins \& William Pagliuca. 1994. The evolution of grammar: Tense, aspect and modality in the languages of the world. Chicago: University of Chicago Press.

Dahl, Östen. 2001. Grammaticalization and the life cycles of constructions. RASK 14. 91-133.

Diewald, Gabriele. 1991. Deixis und Textsorten im Deutschen (Reihe Germanistische Linguistik 118). Tübingen: Niemeyer.

Diewald, Gabriele. 1999. Die Entwicklung der Modalpartikel aber: Ein typischer Grammatikalisierungsweg der Modalpartikeln. In Hans Otto Spillmann \& Ingo Warnke (eds.), Internationale Tendenzen der Syntaktik, Semantik und Pragmatik: Akten des 32. Linguistischen Kolloquiums in Kassel 1997 (Linguistik international 1), 83-91. Frankfurt am Main: Lang.

Diewald, Gabriele. 2006. Discourse particles and modal particles as grammatical elements. In Kerstin Fischer (ed.), Approaches to discourse particles (Studies in Pragmatics 1), 403-425. Amsterdam: Elsevier.

Diewald, Gabriele. 2007. Abtönungspartikel. In Ludger Hoffmann (ed.), Handbuch der deutschen Wortarten, 117-142. Berlin \& New York: Mouton de Gruyter.

Diewald, Gabriele. 2008. Grammatikalisierung, Grammatik und grammatische Kategorien: Überlegungen zur Entwicklung eines grammatikalisierungsaffinen Grammatikbegriffs. In Thomas Stolz (ed.), Grammatikalisierung und grammatische Kategorien (Diversitas Linguarum 21), 1-32. Brockmeyer: Bochum.

Diewald, Gabriele. 2010. On some problem areas in grammaticalization studies. In Katerina Stathi, Elke Gehweiler \& Ekkehard König (eds.), Grammaticalization: Current views and issues (Studies in Language Companion Series 119), 17-50. Amsterdam \& Philadelphia: John Benjamins.

Diewald, Gabriele \& Gisella Ferraresi. 2008. Semantic, syntactic and constructional restrictions in the diachronic rise of modal particles in German: A corpus-based study on the formation of a grammaticalization channel. In Elena Seoane \& María José López-Couso (eds.), Theoretical and empirical issues in grammaticalization (Typological Studies in Language 77), 77-109. Amsterdam \& Philadelphia: Benjamins.

Diewald, Gabriele, Marijana Kresić \& Elena Smirnova. 2009. The grammaticalization channels of evidentials and modal particles in German: integration in textual structures as a common feature. In Maj-Britt Mosegaard Hansen \& Jacqueline Visconti (eds.), Current trends in diachronic semantics and pragmatics (Studies in Pragmatics 7), 193-213. Bingley: Emerald.

Diewald, Gabriele \& Elena Smirnova. submitted. "Paradigmatic integration": The fourth stage in an expanded grammaticalization scenario. In Bert Cornillie, Hubert Cuyckens, Kristin Davidse, Tanja Mortelmans \& Torsten Leuschner (eds.), Papers presented at the conference New Reflections on Grammaticalization 4, Leuven, 16-19 July 2008. Amsterdam \& Philadelphia: John Benjamins.

Diewald, Gabriele \& Ilse Wischer. 2005. Introduction: Reconstructing grammaticalization and the definition of grammar. Paper presented at New Reflections on Grammaticalization 3, Santiago de Compostela, Spain. 19-23 July.

Erman, Britt \& Ulla-Britt Kotsinas. 1993. Pragmaticalization: The case of ba and you know. Studier i modern sprakvetenskap 10. 76-92.

Giacalone Ramat, Anna \& Caterina Mauri. 2009. Introduction. Paper present at the Workshop on Grammaticalization between Semantics and Pragmatics, Pavia, February.

Giacalone Ramat, Anna \& Caterina Mauri. 2010. Dalla continuità temporale al contrasto: La grammaticalizzazione di tuttavia come connettivo avversativo. In Atti del X Congresso della Società Internazionale di Linguistica e Filologia (SILFI), Basilea 30.6-2.7 2008, 449-470. Firenze: Franco Cesati. 
Gohl, Christine \& Susanne Günthner. 1999. Grammatikalisierung von weil als Diskursmarker in der gesprochenen Sprache. Zeitschrift für Sprachwissenschaft 18. 39-75.

Günthner, Susanne. 1999. Entwickelt sich der Konzessivkonnektor obwohl zum Diskursmarker? Grammatikalisierungstendenzen im gesprochenen Deutsch. Linguistische Berichte 180. 409446.

Günthner, Susanne \& Katrin Mutz. 2004. Grammaticalization vs. pragmaticalization? The development of pragmatic markers in German and Italian. In Walter Bisang, Nikolaus P. Himmelmann \& Björn Wiemer (eds.), What makes Grammaticalization? A look from its fringes and its components (Trends in Linguistics: Studies and Monographs 158), 77-107. Berlin \& New York: Mouton de Gruyter.

Haspelmath, Martin. 1998. Does grammaticalization need reanalysis? Studies in Language 22(2). 315-351.

Haspelmath, Martin. 1999. Why is grammaticalization irreversible? Linguistics 37(6). 1043 1068.

Heine, Bernd. 2003. Grammaticalization. In Brian Joseph \& Richard Janda (eds.), The handbook of historical linguistics, 575-601. Oxford: Blackwell.

Helbig, Gerhard. 1988. Lexikon deutscher Partikeln. Leipzig: Enzyklopädie.

Helbig, Gerhard \& Joachim Buscha. 2001. Deutsche Grammatik. Ein Handbuch für den Ausländerunterricht. Berlin: Langenscheidt.

Hentschel, Elke. 1986. Funktion und Geschichte deutscher Partikeln: Ja, doch, halt und eben. Tübingen: Niemeyer.

Himmelmann, Nikolaus P. 1992. Grammaticalization and grammar (Arbeitspapier 16 [Neue Folge]). Köln: Institut für Sprachwissenschaft.

Himmelmann, Nikolaus P. 2004. Lexicalization and grammaticalization: Opposite or orthogonal? In Walter Bisang, Nikolaus P. Himmelmann \& Björn Wiemer (eds.), What makes Grammaticalization? A look from its fringes and its components (Trends in Linguistics: Studies and Monographs 158), 21-42. Berlin \& New York: Mouton de Gruyter.

Jakobson, Roman. 1971 [1957]. Shifters, verbal categories, and the Russian verb. In Selected Writings, Vol. II: Word and language, 130-147. The Hague: Mouton.

Jespersen, Otto. 1992 [1924]. The philosophy of grammar. With a new introduction and index by James D. McCawley. Chicago \& London: University of Chicago Press.

Keil, Martina. 1990. Analyse von Partikeln für ein sprachverstehendes System - am Beispiel telefonischer Zugauskunftsdialoge. Erlangen: Universität Erlangen MA thesis.

König, Ekkehard, Detlef Stark \& Susanne Requardt. 1990. Adverbien und Partikeln: Ein deutschenglisches Wörterbuch. Heidelberg: Julius Groos.

Krivonossov, Aleksej. 1977. Die modalen Partikeln in der deutschen Gegenwartssprache (Göppinger Arbeiten zur Germanistik 214). Göppingen: Kümmerle.

Langacker, Ronald W. 1985. Observations and speculations on subjectivity. In John Haiman (ed.), Iconicity in syntax: Proceedings of a symposium on iconicity in syntax, Stanford, June 24-26, 1983 (Typological Studies in Language 6), 109-150. Amsterdam \& Philadelphia: John Benjamins.

Langacker, Ronald W. 2002. Deixis and subjectivity. In Frank Brisard (ed.), Grounding: The epistemic footing of deixis and reference (Cognitive Linguistics Research 21), 1-27. Berlin \& New York: Mouton de Gruyter.

Lehmann, Christian. 1985. Grammaticalization: Synchronic variation and diachronic change. Lingua e Stile 20. 303-318.

Lehmann, Christian. 1995[1982]. Thoughts on grammaticalization (LINCOM Studies in Theoretical Linguistics 1). München: LINCOM Europa.

Lehmann, Christian. 2004. Theory and method in grammaticalization. Zeitschrift für germanistische Linguistik 32(2), 152-187. 
Lima, José Pinto de. 2002. Grammaticalization, subjectification and the origin of phatic markers. In Ilse Wischer \& Gabriele Diewald (eds.), New reflections on grammaticalization (Typological Studies in Language 49), 363-378. Amsterdam \& Philadelphia: John Benjamins.

Mel'čuk, Igor A. 1976. On suppletion. Linguistics 170. 45-90.

Plungian, Vladimir A. 1998. Грамматические категории, их аналоги и заместители. Диссертаиия на соискание ученой степени доктора филологических наук [Grammatical categories, their analogs and alternatives]. Moscow: Moscow State University habilitation thesis.

Radtke, Petra. 1998. Die Kategorien des deutschen Verbs. Zur Semantik grammatischer Kategorien. Tübingen: Narr.

Tabor, Whitney \& Elizabeth Closs Traugott. 1998. Structural scope expansion and grammaticalization. In Anna Giacalone Ramat \& Paul J. Hopper (eds.), The limits of grammaticalization, 229-272. Amsterdam \& Philadelphia: John Benjamins.

Traugott, Elizabeth Closs. 1989. On the rise of epistemic meanings in English: An example of subjectification in semantic change. Language 65(1). 31-55.

Traugott, Elizabeth Closs. 1999. The rhetoric of counter-expectation in semantic change: A study in subjectification. In Andreas Blank \& Peter Koch (eds.), Historical semantics and cognition (Cognitive Linguistics Research 13), 177-196. Berlin \& New York: Mouton de Gruyter.

Traugott, Elizabeth Closs. 2003. Constructions in grammaticalization. In Brian Joseph \& Richard Janda (eds.), The handbook of historical linguistics, 624-647. Oxford: Blackwell.

Traugott, Elizabeth Closs \& Richard B. Dasher. 2002. Regularity in semantic change (Cambridge Studies in Linguistics 97). Cambridge: Cambridge University Press.

Traugott Elizabeth Closs \& Ekkehard König. 1991. The semantics-pragmatics of grammaticalization revisited. In Elizabeth Closs Traugott \& Bernd Heine (eds.), Approaches to grammaticalization, vol. I, 189-218. Amsterdam \& Philadelphia: John Benjamins.

Vasko, Ildiko \& Thorstein Fretheim. 1997. Some central pragmatic functions of the Norwegian particles altså and nemlig. In Toril Swan \& Olaf Jansen Westvik (eds.), Modality in Germanic languages. Historical and comparative perspectives (Trends in Linguistics: Studies and Monographs 99), 233-292. Berlin \& New York: Mouton de Gruyter.

Wegener, Heide. 1998. Zur Grammatikalisierung von Modalpartikeln. In Irmhild Barz \& Günther Öhlschläger (eds.), Zwischen Grammatik und Lexikon (Linguistische Arbeiten 390), 37-55. Tübingen: Niemeyer.

Wegener, Heide. 2002. The evolution of the German modal particle denn. In Ilse Wischer \& Gabriele Diewald (eds.), New reflections on grammaticalization (Typological Studies in Language 49), 379-394. Amsterdam \& Philadelphia: John Benjamins.

Weydt, Harald. 1969. Abtönungspartikel: Die deutschen Modalwörter und ihre französischen Entsprechungen. Bad Homburg \& Berlin: Gehlen.

Weydt, Harald. (ed.). 1977. Aspekte der Modalpartikeln: Studien zur deutschen Abtönung. Tübingen: Niemeyer.

Weydt, Harald (ed.). 1979. Die Partikeln der deutschen Sprache. Berlin \& New York: Walter de Gruyter.

Weydt, Harald (ed.). 1989. Sprechen mit Partikeln. Berlin \& New York: Walter de Gruyter.

Wiemer, Björn \& Walter Bisang. 2004. What makes grammaticalization? An appraisal of its components and its fringes. In Walter Bisang, Nikolaus P. Himmelmann \& Björn Wiemer (eds.), What makes Grammaticalization? A look from its fringes and its components (Trends in Linguistics: Studies and Monographs 158), 3-20. Berlin \& New York: Mouton de Gruyter. 